\title{
Feeding problems and GI dysfunction in children with asperger syndrome or pervasive developmental disorder not otherwise specified; comparison with their siblings
}

\author{
Vahe Badalyan, Richard H. Schwartz
}

Department of Gastroenterology, Nutrition and Hepatology CNMC, Washington DC, USA.

Email: vbadalyan@gmail.com

Received 2 October 2011; revised 13 November 2011; accepted 24 November 2011.

\section{ABSTRACT}

Objective: There are few previously published studies of feeding problems and/or gastrointestinal dysfunction among children with Asperger syndrome (AS) or Pervasive Developmental Disorder (PDD-NOS), compared to sibling controls. Study Design: On-line parent autism groups $\mathbf{9 0 \%}$ from North America. Statistical analysis: Chi square and binomial logistic regression statistical analysis Results: Completed surveys were received for 64 children with AS, 44 with PDD-NOS, total $=108$ ), and 82 normal sibling matches. Children with high-functioning autism had higher likelihood of frequent ( $>50 \%$ of the time) problematic feeding behaviors and gastrointestinal dysfunction, such as unusual food preferences (OR 23.9, 95\% CI 7.3 - 78.7), insistence on unusual food presentation (OR 5.8, 95\% CI 1.8 - 18.4), and poor mealtime social behavior (OR 16.1, 95\% CI 4.1 64.1). These children also had higher odds of frequent constipation (OR 8.3, 95\% CI 2.2 - 31.9) and fecal incontinence (OR 5.4, 95\% CI 1.1 - 27.3). Nine children in AS/PDD-NOS group (4\%) were believed by parent to have celiac disease $(3 \%$ or $1 \%$ had intestinal biopsy), compared to 2 in control group. Conclusion: $57 \%$ of the AS/PDD-NOS group had frequent unusual food preferences vs. $5 \%$ of controls. Fortyeight percent of children with AS/PDD-NOS had frequent dislikes of new foods, compared to $6 \%$ of controls. For symptoms of specific gastrointestinal dysfunction, children with AS/PDD-NOS had higher prevalence of frequent constipation (30\% vs. $4 \%$ ) and fecal incontinence $(22 \%$ vs. $2 \%)$.

Keywords: Asperger Syndrome; PDD-NOS, Feeding Behaviors; Gastrointestinal Dysfunction; Food Preferences

\section{INTRODUCTION}

An estimated 1 in 110 children in the US and Canada are estimated to have a diagnosis of Autism Spectrum disorder and these rates have been increasing in the past decade [1]. Autism spectrum disorder (ASD), is a heterogeneous group of neuro-developmental disorders that the Diagnostic and Statistical Manual IV-R currently subdivides into three subgroups: Asperger syndrome, pervasive developmental disorder-not otherwise specified (PDD-NOS) which is the most common and has the least precise diagnostic criteria [2], and classical autism [3]. Children with PDD-NOS almost universally have impairments in social reciprocity and communication, without significant repetitive and stereotyped behaviors [4]. Compared to classic autism, they have comparably severe but more circumscribed social communication difficulties with fewer non-social features such as sensory integration or feeding problems. The current draft guidelines of the upcoming DSM-V will mandate repetitive and stereotyped behaviors in addition to major defects in language and communication and socialization [4]

Previous publications have documented increased rates of feeding problems and gastrointestinal dysfunction among children with ASD. Although opinions differ, a majority of published studies on the subject of childhood autism and gastrointestinal problems report higher rates of feeding problems in children with ASD compared to controls [5-13]. The Brief Autism Mealtime Behavior Inventory (BAMBI) has been developed to evaluate the mealtime behavior of children with autism [14]. The BAMBI demonstrated good internal consistency, high test-re-test reliability.

A recent study comparing 48 children ( 3 to 12 years old) with ASD, to their matched siblings found that the ASD group had a mean of 13 eating problems, with lack of food variety predomination while the sibling group had a mean of 5 eating problems [11]. Feeding problems 
included inflexible food preferences (based on food texture, color, smell, presentation, limited variety diets, and specific utensil requirements), oral-motor dyspraxia and disruptive mealtime behaviors, among others. In a survey of 138 children with autism and 298 typically developing children, Schreck and colleagues (2005), found that children with autism had higher rates of refusing most foods, requiring specific utensils, requiring particular food presentation, accepting only pureed or low textured foods, and eating a narrow variety of foods [15]. Smith et al also found that children with ASD had a limited repertoire of foods (35\% vs. 3\%) [8]. Emond et al. (2010) found that caregivers of autistic children reported significantly more frequently feeding slow during early infancy, parent having difficulties feeding the child, and the child being a picky eater [16].

In 2011, investigators from the University of California reported that 249 children on the autism spectrum had significantly more GI problems (42\%) than 163 siblings $(12 \%)$. This study was registry-based and the investigators conducted in-home structured medical history interviews by parent recall. Those children with classic autism had increased odds of having GI problems compared to less severely affected children with ASD [12].

The most common symptoms of GI dysfunction include abdominal pain, dysphagia, gastrointestinal reflux (GER), constipation, withholding stool, and fecal incontinence [15]. Constipation rates among the children with autism was higher than control groups in the studies of Melmed [17], Taylor [18], Afzal [19], Molloy [7], and Smith [8].

In contradistinction, analysis of a database of 211,480 children from the United Kingdom found no difference in gastrointestinal complaints in 96 children diagnosed with ASD compared with 449 nested controls [20]. Investigators from the Mayo Clinic also found no significant associations between autism case status and overall incidence of GI dysfunction [21]. An Australian study concluded that children with early gastrointestinal problems were no more likely to be represented in the upper quartile of scores on the Autism Spectrum Quotient (AQ) scales [4].

The purpose of this study was to compare the prevalence of feeding difficulties and gastrointestinal dysfunction in children with Asperger syndrome and Pervasive Developmental Disorder (so-called high-functioning autism) and their typically developing siblings. Our intention was to use sibling controls in order to control for the influence of social environment.

\section{STUDY DESIGN AND PATIENT POPULATION}

This was a cross-sectional online survey conducted from
February 2009 through April 2009. The lengthy survey instrument included 41 questions pertaining to demographics, family income, developmental milestones, feeding behaviors and odd mannerisms, food preferences, and GI dysfunction at the time when the child was between ages 3 and 12 (see appendix). The survey contained two almost identical parts, one for the child with AS or PDD-NOS and one for the typically-developing sibling. Both parts contained the same 41 questions with the exception of the question pertaining to ASD diagnosis (only available in ASD part). The survey was securely posted online at a commercial survey website http://www.formsite.com (Vroman systems Inc, Chicago, IL). At no point was the survey tool sold and no profits were generated from using the survey tool. The authors bore all the costs associated with publishing the survey online.

The link to the survey was e-mailed repeatedly to national, regional, state, and large city autism organizations and support groups. Parents were asked to complete the survey if they had a child with AS or PDD-NOS. If a parent had several children with ASD, he/she was asked to complete the survey separately for each ASD child. The survey was confidential and anonymous. The survey link contained an introductory statement about the purpose of the survey, voluntary participation, risks and benefits, and contacts of investigators and IRB officer.

The drafts of the survey were pre-tested on 10 parents of ASD children from a pediatric practice in Vienna, VA, and reviewed by local specialists in developmental/behavioral pediatrics, and pediatric gastroenterology. The survey protocol was approved without full formal review by Inova Fairfax Hospital Institutional Review Board.

\subsection{Definitions Used for This Study}

Children were defined as having Asperger syndrome or PDD-NOS if the parents indicated so in the survey and, if the diagnosis was made by a primary care or pediatric sub-specialist physician or psychologist.

Definitions used in this study: We categorized the frequencies of feeding behaviors and gastrointestinal problems into "Never", "Rarely" (less than $10 \%$ of the time), "Sometimes" (10\%- $50 \%$ of the time), and "Often" (more than $50 \%$ of the time).

"Diarrhea" was defined as passing at least three watery unformed stools in a day. "Constipation" was defined as hard or painful stools passed less than three times per week.

"Pica" was defined as the ingestion of unusual nonfood items such as dirt or string.

\subsection{Statistical Methods}

Data was analyzed using SPSS version 18 (SPSS Inc. 
Chicago, Illinois). Descriptive statistics (means and standard deviations) were used for continuous variables, and proportions were used for categorical variables. Fischer's exact test was used to compare dichotomous variables pertaining to feeding and gastrointestinal dysfunction between the groups. To control for influences of variables pertaining to age, gender, degree of developmental impairment, medical problems, country, food allergies, and dietary restrictions, binomial logistical regression models were created with these variables being included as independent variables, along with the autistic spectrum disorder variable (case vs. control). The variables pertaining to feeding and gastrointestinal dysfunction were included one by one in the regression model as a dependent variable.

\section{RESULTS}

Surveys were completed for 64 children with Asperger Syndrome, 44 children with PDD-NOS (combined total $=108$ ), and 82 of their typically-developing siblings. All participants were between the ages of 3 and 12 years. Males comprised $88 \%$ of the combined (AS/PDD-NOS) group and $50 \%$ of the control group $(\mathrm{p}<0.001)$. Mean ages at the time of the survey were 7.9 years and 7.7 years in the ASD and control groups, respectively ( $\mathrm{p}=$ 0.54 , NS) (Table 1).

U.S. respondents comprised $85 \%$ of the ASPDD-NOS group and $78 \%$ of the control group ( $p=0.25, \mathrm{NS})$. The highest numbers of U.S. respondents came from Virginia, Kansas, Texas, Indiana, and Missouri. Fifteen percent of completed responses came from Canada. A bare majority $(52 \%)$ of the parent responders reported that their household income in 2008 exceeded $\$ 75,000$ per year ( $p$ $=0.84, \mathrm{NS}$ ). Approximately $5 \%$ of the control group was enrolled in Medicaid.

Cross-tabulations of children with Asperger syndrome and PDD-NOS showed that the two groups were, in general, similar in terms of most developmental mile- stones, food preferences and gastrointestinal dysfunction (chi square $\mathrm{p}$ values $>0.05$ ) (Tables 2 and 3). There were some specific developmental milestone differences between children with AS and those with PDD-NOS. The mean age at the time of diagnosis was 4-years for children with PDD-NOS versus 6.2 years for children with AS (independent samples t-test, $\mathrm{p}$ value $<0.001$ ). Sixtyseven percent of PDD-NOS group versus $86 \%$ of children in the AS group were toilet trained by age of 4 (Chi square $\mathrm{P}$ value $=0.029$ ). Acquisition of language by the age of 4 years was achieved by $55 \%$ of PDD-NOS group and by $88 \%$ of Asperger group (Chi-square $\mathrm{P}$ value $<$ 0.001) (Table 2).

Because of the small number of differences for feeding problems or GI dysfunction, children with AS or PDD-NOS were combined into a single combined study group for subsequent analysis. Their typically-developing siblings were also combined into a single control group.

There were major differences between children with the combined AS/PDD-NOS and sibling controls in reportedly having any major developmental problem (AS/ PDD-NOS $=200[96 \%]$ compared to $9[6 \%]$ in control group, $\mathrm{p}<0.000, \mathrm{OR}=337.8, \mathrm{CI}=114-1000.8)$, disortions or paucity of social play (AS/PDD-NOS $=103 \mathrm{vs}$ controls $=2, \mathrm{p}<0.000, \mathrm{OR}=42.9, \mathrm{CI}=5.3-349.9$ ), odd routines $(\mathrm{AS} / \mathrm{PDD}-\mathrm{NOS}=139$ vs control group $=3$, $\mathrm{p}<0.000, \mathrm{OR}=107.4, \mathrm{CI}=31.3$ - 369.1), never spoke by age 4 years (AS/PDD-NOS $=40$ vs controls $=1, \mathrm{p}<$ 0.000, OR $=42.9, \mathrm{CI}=5.3$ - 349.9) (Table 3).

The combined AS/PDD-NOS group differed signifycantly from the control group for frequent disruptive feeding problems. These included obsessional food preferences (i.e. insistence on: a. specific food colors, shapes, or textures, insistence on eating food with specific utensils/dishes, fear of new foods, and disruptive family mealtime behavior, (Table 4). Unusual food preference (frequency $>50 \%$ of time) was present for 127

Table 1. Study participants.

\begin{tabular}{|c|c|c|c|c|c|}
\hline & \multirow{2}{*}{$\begin{array}{l}\text { Control } \\
\mathrm{n}=82\end{array}$} & \multicolumn{3}{|c|}{ AS/PDD Combined group } & \multirow[t]{2}{*}{ Significant } \\
\hline & & $\%$ & $\mathrm{n}=108$ & $\%$ & \\
\hline Age & 7.7 & & 7.9 & & $\mathrm{p}=0.54$ \\
\hline St dev & 2.8 & & 2.7 & & \\
\hline Male gender & 41 & $50 \%$ & 95 & $88 \%$ & $\mathrm{p}<0.001$ \\
\hline Family income $>\$ 75000 /$ year & 44 & $54 \%$ & 55 & $51 \%$ & $\mathrm{p}=0.84$ \\
\hline Developmental Milestones Spoke by age 4 & 79 & $96 \%$ & 80 & $74 \%$ & $\mathrm{p}<0.001$ \\
\hline Spoon trained by age 3 & 79 & $96 \%$ & 83 & $77 \%$ & $\mathrm{p}<0.001$ \\
\hline Toilet trained by age 4 & 77 & $94 \%$ & 83 & $77 \%$ & $\mathrm{p}<0.001$ \\
\hline
\end{tabular}


Table 2. Occurrence of select behaviors and GI symptoms that were frequent.

\begin{tabular}{|c|c|c|c|c|c|}
\hline GI symptoms & Asperger $(n=134)$ & PDD-NOS $(\mathrm{n}=71)$ & $\begin{array}{l}\text { Combined Asperger and } \\
\text { PDD-NOS }(\mathrm{n}=6)\end{array}$ & Controls $(\mathrm{n}=160)$ & Chi-Square $\mathrm{P}$ value \\
\hline vomiting & 12 & 2 & 2 & 5 & $\mathrm{p}=0.002$ \\
\hline$\%$ & $9.0 \%$ & $2.8 \%$ & $33.3 \%$ & $3.1 \%$ & \\
\hline diarrhea & 10 & 12 & 2 & 4 & $<0.001$ \\
\hline$\%$ & $7.5 \%$ & $16.9 \%$ & $33.3 \%$ & $2.5 \%$ & \\
\hline constipation & 35 & 25 & 2 & 9 & $<0.001$ \\
\hline$\%$ & $26.1 \%$ & $35.2 \%$ & $33.3 \%$ & $5.6 \%$ & \\
\hline soiling & 27 & 21 & 5 & 7 & $<0.001$ \\
\hline$\%$ & $20.1 \%$ & $29.6 \%$ & $83.3 \%$ & $4.4 \%$ & \\
\hline difficulty swallowing & 6 & 11 & 2 & 4 & $<0.001$ \\
\hline$\%$ & $4.5 \%$ & $15.5 \%$ & $33.3 \%$ & $2.5 \%$ & \\
\hline reflux & 17 & 10 & 3 & 11 & $\mathrm{p}=0.004$ \\
\hline$\%$ & $12.7 \%$ & $14.1 \%$ & $50.0 \%$ & $6.9 \%$ & \\
\hline abdominal pain & 11 & 5 & 2 & 6 & $\mathrm{p}=0.02$ \\
\hline$\%$ & $8.2 \%$ & $7.0 \%$ & $33.3 \%$ & $3.8 \%$ & \\
\hline failure to thrive & 31 & 17 & 3 & 10 & $<0.001$ \\
\hline$\%$ & $23.3 \%$ & $25.0 \%$ & $50.0 \%$ & $6.4 \%$ & \\
\hline \multirow[t]{2}{*}{ any diet restriction } & 30 & 19 & 3 & 12 & $<0.001$ \\
\hline & $22.4 \%$ & $26.8 \%$ & $50.0 \%$ & $7.5 \%$ & \\
\hline \multirow[t]{2}{*}{ any food allergy } & 30 & 18 & 4 & 21 & $<0.002$ \\
\hline & $22.4 \%$ & $25.4 \%$ & $66.7 \%$ & $13.1 \%$ & \\
\hline
\end{tabular}

Table 3. Deviation from normal developmental milestones.

\begin{tabular}{|c|c|c|c|c|c|c|}
\hline & \multicolumn{2}{|c|}{ AS/PDD-NOS } & \multicolumn{2}{|c|}{ Controls } & \multirow{2}{*}{$\begin{array}{l}\text { Fischer's } \\
\text { exact test }\end{array}$} & \multirow{2}{*}{$\begin{array}{l}\text { Logistic regression odds } \\
\text { ratio }(95 \% \mathrm{CI})\end{array}$} \\
\hline & $\mathrm{n}=211$ & $\%$ & $\mathrm{n}=160$ & $\%$ & & \\
\hline No Social Play & 103 & $49 \%$ & 2 & $1 \%$ & 0.000 & $53.9(12.8-227.2)$ \\
\hline Odd Mannerisms & 174 & $82 \%$ & 4 & $3 \%$ & 0.000 & $159.4(52.5-483.9)$ \\
\hline Odd Routines & 139 & $66 \%$ & 3 & $2 \%$ & 0.000 & $107.4(31.3-369.1)$ \\
\hline Any Major Developmental Problem & 200 & $95 \%$ & 9 & $6 \%$ & 0.000 & $337.8(114-1000.8)$ \\
\hline Mental Disability & 6 & $3 \%$ & 2 & $1 \%$ & 0.474 & $1.3(0.2-8.7)$ \\
\hline
\end{tabular}

or $60 \%$ of the AS/PDD-NOS group vs. 9 or $6 \%$ of the control group $(\mathrm{p}<0.001, \mathrm{OR}=38.4, \mathrm{CI}=15.4-95.8)$ (Table 4). Disruptive family mealtime behavior was noted for 74 or $35 \%$ of the AS/PDD-NOS group vs. 7 or
$4 \%$ or the control group $(\mathrm{p}<0.001, \mathrm{OR}=9.9, \mathrm{CI}=4$ 24.7).

The combined AS/PDD-NOS group differed significantly from the control group by the prevalence of se- 
Table 4. Abnormal Feeding behaviors, frequency $>50 \%$ of the time.

\begin{tabular}{|c|c|c|c|c|c|}
\hline $\begin{array}{c}\text { Frequent ( }>50 \%) \text { occurrence of select } \\
\text { behaviors and gastrointestinal symptoms }\end{array}$ & $\begin{array}{l}\text { Asperger } \\
(\mathrm{n}=134)\end{array}$ & $\begin{array}{l}\text { PDD-NOS } \\
(\mathrm{n}=71)\end{array}$ & $\begin{array}{l}\text { Combined Asperger and } \\
\text { PDD-NOS }(\mathrm{n}=6)\end{array}$ & $\begin{array}{l}\text { Controls } \\
(\mathrm{n}=160)\end{array}$ & $\begin{array}{l}\text { Chi-Square } \mathrm{P} \\
\text { value }\end{array}$ \\
\hline unusual food preferences & 76 & 47 & 4 & 6 & $<0.001$ \\
\hline$\%$ & $56.7 \%$ & $66.2 \%$ & $66.7 \%$ & $3.8 \%$ & \\
\hline insistence on using utensils & 32 & 18 & 2 & 9 & $<0.001$ \\
\hline$\%$ & $23.9 \%$ & $25.4 \%$ & $33.3 \%$ & $5.6 \%$ & \\
\hline dislike of new foods & 62 & 42 & 5 & 9 & $<0.001$ \\
\hline$\%$ & $46.3 \%$ & $59.2 \%$ & $83.3 \%$ & $5.6 \%$ & \\
\hline fear of new foods & 73 & 50 & 3 & 20 & $<0.001$ \\
\hline$\%$ & $54.5 \%$ & $70.4 \%$ & $50.0 \%$ & $12.5 \%$ & \\
\hline eating nonfood items (Pica) & 12 & 9 & 2 & 2 & $<0.001$ \\
\hline$\%$ & $9.0 \%$ & $12.7 \%$ & $33.3 \%$ & $1.3 \%$ & \\
\hline Disruptive family mealtime & 41 & 29 & 4 & 7 & $<0.001$ \\
\hline behavior & $30.6 \%$ & $40.8 \%$ & $66.7 \%$ & $4.4 \%$ & \\
\hline Disruptive school mealtime behavior & 14 & 12 & 3 & 1 & $<0.001$ \\
\hline$\%$ & $10.4 \%$ & $16.9 \%$ & $50.0 \%$ & $.6 \%$ & \\
\hline unusual posturing during mealtime & 24 & 9 & 2 & 5 & $<0.001$ \\
\hline$\%$ & $17.9 \%$ & $12.7 \%$ & $33.3 \%$ & $3.1 \%$ & \\
\hline oral motor problems & 11 & 11 & 3 & 4 & $<0.001$ \\
\hline$\%$ & $8.2 \%$ & $15.5 \%$ & $50.0 \%$ & $2.5 \%$ & \\
\hline
\end{tabular}

lected symptoms of frequent feediang behavior problems (Table 5) and GI dysfunction (Table 6). ASD chil- dren often had higher prevalence of (frequency $>50 \%$ of the time) constipation ( $30 \%$ vs. $4 \%, \mathrm{p}<0.001, \mathrm{OR}=8.1, \mathrm{CI}$ $=3.5-19)$, soiling $(22 \%$ vs. $2 \%, \mathrm{p}<0.001, \mathrm{OR}=6.7, \mathrm{CI}$ $=2.7-17)$, and failure to thrive $(22 \%$ vs. $7 \%, \mathrm{p}<0.001$, $\mathrm{OR}=4.5, \mathrm{CI}=2.1-9.4)$. Higher proportions of ASD children were or had been on a restrictive diet $(24 \%)$ compared to the controls $(9 \%)(p<0.006)$.). Regression models additionally revealed that having been on at least one restrictive diet was associated with increased the odds of constipation $(\mathrm{OR}=3.38, \mathrm{CI}=1.14-10.04, \mathrm{p}=$ 0.029).

There were no significant differences in abdominal pain, reflux, or other gastrointestinal pathology between the two study groups (Table 6).

Duration of feeding problems: When ASD or control children exhibited unusual mealtime preferences and behaviors; these mostly were long term (lasted $>6$ months).

\section{DISCUSSION}

In accord with several previous studies, our study re- veals important new information about the high prevalence, frequency and duration of feeding problems, mealtime misbehaviors, and GI dysfunction in children with Asperger syndrome and PDD-NOS (ASD). The study design addresses and cures some of the criticism of previous published studies of gastrointestinal dysfunction in children with autism. This manuscript contains information only about AS and PDD-NOS and excludes the large category of classic autism. Parents of children with ASD are often accurate in diagnosing autism based on Internet-implemented parent report [22]. We accepted only children who had diagnostic criteria for AS or PDD-NOS outlined by the DSM-IV-R manual. We excluded from analysis all survey responses in which the diagnosis of AS or PDD-NOS was not made by professionals (see Survey instrument in appendix). We did not obtain verification of the diagnosis of AS or PDDNOS by independent review of the child's medical records or by administration of standardized diagnostic tests for AS or PDD-NOS.

Is the diagnosis of AS or PDD-NOS accurate? Should the diagnosis for a substantial percentage of participants with ASD be erroneous, we are at a loss to account for 
Table 5. Frequent feeding/behavior problems during meals.

\begin{tabular}{|c|c|c|c|c|c|c|c|}
\hline \multirow{2}{*}{ Feeding Problems/Behavior } & \multicolumn{2}{|c|}{ Children with ASD } & \multicolumn{2}{|c|}{ Controls } & \multirow{2}{*}{$\begin{array}{l}\text { Fischer's } \\
\text { exact test }\end{array}$} & \multirow{2}{*}{$\begin{array}{l}\text { Logistic regression odds } \\
\quad \text { ratio }(95 \% \mathrm{CI})\end{array}$} & \multirow{2}{*}{$\mathrm{P}$} \\
\hline & $\mathrm{n}=211$ & $\%$ & $\mathrm{n}=160$ & $\%$ & & & \\
\hline Unusual food preferences & 127 & $60 \%$ & 6 & $4 \%$ & 0.000 & $38.4(15.4-95.8)$ & 0.000 \\
\hline Dislike of new foods & 109 & $52 \%$ & 9 & $6 \%$ & 0.000 & $22.2(9.4-52.8)$ & 0.000 \\
\hline Fear of new foods & 126 & $60 \%$ & 20 & $13 \%$ & 0.000 & $11.3(6.1-21)$ & 0.000 \\
\hline Eating non-food items (Pica) & 23 & $11 \%$ & 2 & $1 \%$ & 0.000 & $19(2.4-152)$ & 0.006 \\
\hline Disruptive family meal-time & 74 & $35 \%$ & 7 & $4 \%$ & 0.000 & $9.9(4-24.7)$ & 0.000 \\
\hline \multicolumn{8}{|l|}{ behaviors } \\
\hline Unusual posturing \& meals & 35 & $17 \%$ & 5 & $3 \%$ & 0.000 & $7.8(2.5-23.7)$ & 0.000 \\
\hline Oral-motor problems & 25 & $12 \%$ & 4 & $3 \%$ & 0.001 & $5.7(1.5-21)$ & 0.009 \\
\hline
\end{tabular}

Table 6. Frequent occurrence ( $<50 \%$ of time) of GI dysfunction.

\begin{tabular}{|c|c|c|c|c|c|c|c|}
\hline \multirow{2}{*}{ Gastrointestinal Symptom } & \multicolumn{2}{|c|}{ Children with ASD } & \multicolumn{2}{|c|}{ Controls } & \multirow{2}{*}{$\begin{array}{l}\text { Fischer's } \\
\text { exact test }\end{array}$} & \multirow{2}{*}{$\begin{array}{l}\text { Logistic regression odds } \\
\text { ratio }(95 \% \mathrm{CI})\end{array}$} & \multirow{2}{*}{$\mathrm{P}$} \\
\hline & $\mathrm{n}=211$ & $\%$ & $\mathrm{n}=160$ & $\%$ & & & \\
\hline Constipation & 62 & $29 \%$ & 9 & $6 \%$ & 0.000 & $8.1(3.5-19)$ & 0.000 \\
\hline Soiling & 53 & $25 \%$ & 7 & $4 \%$ & 0.000 & $6.7(2.7-17)$ & 0.000 \\
\hline Vomiting & 16 & $8 \%$ & 5 & $3 \%$ & 0.073 & $1.9(0.5-6.9)$ & 0.305 \\
\hline Diarrhea & 24 & $11 \%$ & 4 & $3 \%$ & 0.001 & $3.9(1-14.8)$ & 0.043 \\
\hline Abdominal Pain & 18 & $9 \%$ & 6 & $4 \%$ & 0.087 & $2(0.7-6.3)$ & 0.220 \\
\hline Failure To Thrive & 51 & $24 \%$ & 10 & $6 \%$ & 0.000 & $4.5(2.1-9.4)$ & 0.000 \\
\hline Any Diet Restriction & 52 & $25 \%$ & 12 & $8 \%$ & 0.000 & $3.1(1.4-7.1)$ & 0.006 \\
\hline Any Food Allergy & $\underline{52}$ & $\underline{25 \%}$ & $\underline{21}$ & $\underline{13 \%}$ & $\underline{0.006}$ & $\underline{2.4(1.2-4.5)}$ & $\underline{0.009}$ \\
\hline Celiac Disease & 9 & $4 \%$ & 2 & $1 \%$ & 0.703 & $2.1(0.2-19)$ & \\
\hline
\end{tabular}

the large differences between subjects and sibling controls in gender ratio, achievement of developmental milestones, feeding problems, and gastrointestinal complaints.

Strengths of this survey study include: 1) posting the survey on line in a parallel, split-screed format with questions about children 3 - 12-years old with AS or PDD-NOS on the left side of the split screen, and questions relating to the sibling control on the right side; 2) the wide geographic distribution (no state contributed more than $30 \%$ of the U.S. total) and responses from a large number of small towns and cities; 3) Canadian participation; 4) sibling controls; 5) specific developmental and social milestones, and data collection detailing frequency and duration of mealtime feeding problems and GI dysfunction.

Self-criticism of survey methodology: We excluded parents who are not members of ASD support groups. We admittedly captured respondents who express strong opinions on the subject, respondents with high socioeconomic status, and those who are computer literate.

This age range ( 3 - 12-year old) was selected because based on our assumptions that: 1) high-functioning autism is infrequently diagnosed before the age of 3,2 ) feeding patterns and behaviors of children frequently mature after age three years and tend to remain relatively stable until adolescence, 3) eating patterns of children over 12-years are difficult to monitor due to significant amount of time spent outside home.

The survey instrument was developed based on our review of the literature and our own clinical experiences, as well as using comments and suggestions from parents and developmental pediatricians. We did not undertake formal testing of the survey instrument to assess its construct validity and reliability.

The mean age of diagnosis of children with PDDNOS (4.4 years), was significantly younger than the mean age at diagnosis of the Asperger Syndrome group 
(7.7 years). This may not be a weakness of the study. Children with PDD-NOS have many more deficits in language and communication and the delay in language acquisition attracts the attention of parent, extended family, and physician. The diagnosis of Asperger Syndrome is usually made later than that of PDD-NOS because language delay is not so severe.

We did not include a formal standardized diagnostic test for Asperger syndrome to keep the time to complete the questionnaire relatively short.

In agreement with results of our study, Olmstead County children with ASD were more likely to manifest feeding issues, food selectivity and constipation [21]. In that study, as in ours, there was no evidence of an increase in celiac disease in ASD children compared to the control group. There are no data, however, to ascertain whether the study group in the Olmstead county Minnesota, study had acute, chronic, or some combination of GI dysfunction [21]. We also do not know about the specifics of "strange feeding issues and/or food selectivity" in that study.

In our survey, more than 52 children $(25 \%)$ in the AS/PDD-NOS group had been on (or currently are on) restricted diets, most often, casein-free or gluten-free, $(p$ $<0.001)$ compared to the sibling control group $(\mathrm{OR}=$ 3.1 , CI $=1.4-7.1)$. Only $1 \%$ of those children on a gluten-free diet had a biopsy-proven diagnosis of celiac disease. A multidisciplinary panel of experts recently reviewed the medical literature on the diagnostic evaluation and management of GI problems in children with ASD [23]. Statement 12 of their consensus notes: "available research data do not support the use of a casein-free diet, a gluten-free diet, or combined gluten-free, caseinfree (GFCF) diet as a primary treatment for individuals with ASDs."

\section{CONCLUSIONS}

In a North American on-line survey of many parent support groups for ASD children, children age 3 - 12 years with Asperger syndrome and PDD-NOS have a higher prevalence of abnormal feeding behaviors and gastrointestinal dysfunction compared to their non-ASD siblings. Asperger and PDD-NOS groups were similar in the number and frequency and duration of feeding problems, disruptive mealtime misbehavior, and GI dysfunction.

\section{REFERENCES}

[1] Autism and Developmental Disabilities Monitoring Network Surveillance Year 2006 Principal Investigators, Centers for Disease Control and Prevention, Prevalence of Autism Spectrum Disorders (2006) Morbidity and Mortality Weekly Report (MMWR), United States, 18
December, 2009/58(SS10), 1-20.

[2] Mandy, W., Charman, T., Gilmour, J. and Skuse, D. (2011). Toward specifying pervasive developmental disorder-Not otherwise specified. Autism Research, 4, 121-131. doi:10.1002/aur.178

[3] American Psychiatric Association (2000) Diagnostic and statistical manual of mental disorders. 4th Edition, American Psychiatric Association, Washington DC.

[4] Whitehouse, A.J., Mayberry, M., Wray, J.A. and Hickey, M. (2011) No association between early gastrointestinal problems and autistic-like traits in the general population. Developmental Medicine \& Child Neurology, 53, 457462. doi:10.1111/j.1469-8749.2011.03915.x

[5] Martins, Y., Young, R.L. and Robson, D.C. (2008) Feeding and eating behaviors in children with autism and typically developing children. Journal of Autism and Developmental Disorders, 38, 1878-1887. doi:10.1007/s10803-008-0583-5

[6] Matson, J.L., Fodstad, J.C. and Dempsey, T. (2009) The relationship of children's feeding problems to core symptoms of autism and PDD-NOS. Research in Autism Spectrum Disorders, 3,759-766. doi:10.1016/j.rasd.2009.02.005

[7] Molloy, C.A. and Manning-Courtney, P. (2003) Prevalence of chronic gastrointestinal symptoms in children with autism and autistic spectrum disorders. Autism, 7, 165-171. doi:10.1177/1362361303007002004

[8] Smith, R.A., Farnworth, H., Wright, B. and Allgar, V. (2009) Are there more bowel symptoms in children with autism compared to normal children and children with other developmental and neurological disorders? A case control study. Autism, 13, 343-355.

doi:10.1177/1362361309106418

[9] Schreck, K.A., Williams, K. and Smith, A.F. (2004) A comparison of eating behaviors between children with and without autism. Journal of Autism and Developmental Disorders, 34, 433-438. doi:10.1023/B:JADD.0000037419.78531.86

[10] Kodak, T. and Piazza, C.C. (2008) Assessment and behavioral treatment of feeding and sleeping disorders in children with autism spectrum disorders. Child \& Adolescent Psychiatric Clinics of North America, 17, 887 890. doi:10.1016/j.chc.2008.06.005

[11] Nadon, G., Feldman, D.E., Dunn, W. and Gisel, E. (2011) Mealtime problems in children with autism spectrum disorder and their typically developing siblings: A comparison study. Autism, 15, 98-113. doi:10.1177/1362361309348943

[12] Wang, L.W., Tancredi, D.J. and Thomas, D.W. (2011) The prevalence of gastrointestinal problems in children across the United States with autism spectrum disorders from families with multiple affected members. Journal of Developmental \& Behavioral Pediatrics, 32, 351-360. doi:10.1097/DBP.0b013e31821bd06a

[13] Provost, B., Crowe, T.K., Osbourn, P.L., McClain, C. and Skipper, B.J. (2010) Mealtime behaviors of preschool children: Comparison of children with autism spectrum disorder and children with typical development. Physical \& Occupational Therapy in Pediatrics, 30, 220-233. doi:10.3109/01942631003757669

[14] Lukens, C.T. and Linsheid, T.R. (2008) Development and validation of an inventory to assess mealtime behavior 
problems in children with autism. Journal of Autism and Developmental Disorders, 38, 342-352.

doi:10.1007/s10803-007-0401-5

[15] Schreck, K.A. and Williams, K. (2006) Food preferences and factors influencing food selectivity for children with autism spectrum disorders. Research in Developmental Disabilities, 27, 353-363.

doi:10.1016/j.ridd.2005.03.005

[16] Emond, A., Emmett, P., Steer, C. and Golding, J. (2010) Feeding symptoms, dietary patterns, and growth in young children with autism spectrum disorders. Pediatrics, 126, e337-e342. doi:10.1542/peds.2009-2391

[17] Melmed, R.D., Schneider, C.K. and Fabes, R.A. (2000) Metabolic markers and gastrointestinal symptoms in children with autism and related disorders. Journal of Pediatric Gastroenterology and Nutrition, 31, S31-32.

[18] Taylor, B., Miller, E., Lingam,R., Andrews, N., Simmons, A. and Stowe, J. (2002) Measles, mumps, and rubella vaccination and bowel problems or developmental regression in children with autism: Population study. British Medical Journal (BMJ), 324, 393-396. doi:10.1136/bmj.324.7334.393

[19] Afzal, N., Murch, S., Thirrupathy, K., et al. (2003) Con- stipation with acquired megarectum in children with autism. Pediatrics, 112, 939-942.

doi:10.1542/peds.112.4.939

[20] Black, C., Kaye, J.A. and Jick, H. (2002) Relation of childhood gastrointestinal disorders to autism: Nested case-control study using data from the UK General Practice Research Database. British Medical Journal (BMJ), 325, 419-421. doi:10.1136/bmj.325.7361.419

[21] Ibrahim, S.H., Voigt, R.G., Katusic, S.K., et al. (2009) Incidence of gastrointestinal symptoms in children with autism: A population-based study. Pediatrics, 124, 680686. doi:10.1542/peds.2008-2933

[22] Lee, H., Marvin, A.R., Watson, T., et al. (2010) Accuracy of phenotyping of autistic children based on Internet implemented parent report. American Journal of Medical Genetics Part B: Neuropsychiatric Genetics, 153B, 1119-1126.

[23] Buie, T., Campbell, D.B., Fuchs, G.J., Furuta, G.T., Levy, J., Van de Water, J., et al. (2010) Evaluation, diagnosis, and treatment of gastrointestinal disorders in indiviuals with ASDs: A consensus report. Pediatrics, 125, S1-S18. doi:10.1542/peds.2009-1878C 


\section{APPENDIX}

\section{SURVEY INSTRUMENT}

\section{**SURVEY OF FEEDING AND OTHER DIGESTIVE PROBLEMS IN CHILDREN WITH AUTISM} SPECTRUM DISORDERS

By filling out the following survey, you can help pediatricians and other health professionals learn more about certain problems in children with autism spectrum disorders (ASDs). Such problems include unusual food preferences; aversion to certain food colors, textures, and types; ingestion of non-food items; very restricted choices of foods; special diets; sensory processing disorders; oral-motor swallowing problems; vomiting, diarrhea, or constipation; and symptoms of gastroesophageal reflux (GERD) and its complications, such as erosive esophagitis, and food allergies.

Questions in Column "A" pertain to your child with ASD when he/she was ages 3 - 12 years, even if he/she is older now. In Column "B", we ask the same questions for a sibling of your ASD child, closest to him/her in age. Please check the applicable box below and follow the instructions.

\begin{tabular}{lll}
\hline$\square$ I have at least one child with ASD and at least one child who is ASD-free & $\rightarrow$ & Complete both columns "A" and "B" \\
$\square$ I have at least one child with ASD, and no children who are ASD-free & $\rightarrow$ & Complete column "A" only \\
$\square$ I have no children with ASD, and at least one child who is ASD-free & $\rightarrow$ & Complete column "B" only \\
\hline
\end{tabular}

Please FILL IN the blanks or CHECK the best choice of the following questions:

\begin{tabular}{|c|c|c|}
\hline & $\begin{array}{c}\text { Column A } \\
\text { Child with Autistm Spectrum Disorder }\end{array}$ & $\begin{array}{l}\text { Column B } \\
\text { Child without Autism Spectrum Disorder } \\
\text { (control child) }\end{array}$ \\
\hline \multirow{2}{*}{\multicolumn{3}{|c|}{$\begin{array}{l}\text { Please provide the last } 4 \text { digits of your } \\
\text { phone number for tracking purposes. }\end{array}$}} \\
\hline & & \\
\hline Current age and gender of your child & years $\square$ Male $\square$ Female & years $\square$ Male $\square$ Female \\
\hline $\begin{array}{l}\text { What is your child's diagnosis? } \\
\text { (Please check all that apply) }\end{array}$ & $\begin{array}{l}\square \text { Autism } \\
\square \text { Pervasive developmental disorder, NOS } \\
\square \text { Sensory integration disorder } \\
\square \text { Asperger syndrome } \\
\square \text { Static encephalopathy } \\
\square \text { Other (please specify) }\end{array}$ & $\begin{array}{l}\text { Child without Autistic Spectrum Disorder } \rightarrow \\
\text { Proceed to the next question }\end{array}$ \\
\hline Age at the time of diagnosis & years & $\begin{array}{l}\text { Child without Autistic Spectrum Disorder } \rightarrow \\
\text { Proceed to the next question }\end{array}$ \\
\hline $\begin{array}{l}\text { Was the diagnosis made by a child } \\
\text { neurologist, child psychiatrist, psy- } \\
\text { chologist, general pediatrician, family } \\
\text { physician, or developmental pediatric- } \\
\text { cian? }\end{array}$ & $\begin{array}{l}\square \text { Yes } \\
\square \text { No (who diagnosed your child? } \\
\square \text { Uncertain }\end{array}$ & $\begin{array}{l}\text { Child without Autistic Spectrum Disorder } \rightarrow \\
\text { Proceed to the next question }\end{array}$ \\
\hline Check all that apply to your child & $\begin{array}{l}\square \text { Met developmental milestones } \\
\square \text { Speaking and understanding appropriately by } 4 \\
\text { years of age. } \\
\square \text { Never spoke fluently } \\
\square \text { Difficulty with sustained meaningful interactive } \\
\text { play with same-age child by the age of } 4 \text { years } \\
\square \text { Unusual mannerisms or demanding same rou- } \\
\text { tine over and over }\end{array}$ & $\begin{array}{l}\text { a. } \square \text { Met developmental milestones } \\
\text { b. } \square \text { Speaking and understanding appropriately by } \\
4 \text { years of age. } \\
\text { c. } \square \text { Never spoke fluently } \\
\text { d. } \square \text { Difficulty with sustained meaningful interac- } \\
\text { tive play with same-age child by the age of } 4 \\
\text { years } \\
\text { e. } \square \text { Unusual mannerisms or demanding same } \\
\text { routine over and over }\end{array}$ \\
\hline $\begin{array}{l}\text { Does (did) your child have any of the } \\
\text { following neurological/developmental/ } \\
\text { genetic conditions? (Please check all } \\
\text { that apply) }\end{array}$ & $\begin{array}{ll}\square & \text { Seizures } \\
\square & \text { Down syndrome } \\
\square & \text { Hearing disability } \\
\square & \text { Mental retardation } \\
\square & \text { Other (please specify) } \\
\square & \text { Not applicable }\end{array}$ & $\begin{array}{l}\square \text { Seizures } \\
\square \text { Down syndrome } \\
\square \text { Hearing disability } \\
\square \text { Mental retardation } \\
\square \text { Other (please specify) } \\
\square \text { Not applicable }\end{array}$ \\
\hline
\end{tabular}




\begin{tabular}{|c|c|}
\hline $\begin{array}{l}\text { Does (did) your child have any other } \\
\text { medical conditions? }\end{array}$ & $\begin{array}{l}\square \text { Yes (please specify } \\
\square \text { No } \\
\square \text { Uncertain }\end{array}$ \\
\hline $\begin{array}{l}\text { At what age did your child learn to use } \\
\text { spoon/fork? }\end{array}$ & _ years $\square$ not yet using spoon / fork \\
\hline $\begin{array}{l}\text { Restricted diet at ages } 3-12 \text { years? } \\
\text { (Please check all that apply) }\end{array}$ & $\begin{array}{ll}\text { a. } \square \text { Gluten-free } & \\
\text { b. } \square \text { Soy-free } & \text { f. } \square \text { Feingold diet } \\
\text { c. } \square \text { Dairy (casein)- } & \text { g. } \square \text { Rotation diet } \\
\text { free } & \text { h. } \square \text { No } \\
\text { d. } \square \text { Carbohydrate diet } & \text { i. } \square \text { Uncertain } \\
\text { e. } \square \text { Candida diet } & \end{array}$ \\
\hline
\end{tabular}

Duration of typical dinnertime with a. $\square \leq 30$ minutes \begin{tabular}{ll} 
family at ages $3-12$ years? & b. $\square 31-45$ minutes \\
\hline c. $\square$ 46-60 minutes
\end{tabular}

d. $\square 61-90$ minutes
e. $\square>90$ minutes
a. $\square$ Yes (please specify
b. $\square$ No
c. $\square$ Uncertain
a. $\square$ Gluten-free
b. $\square$ Soy-free $\quad$ f. $\square$ Feingold diet
c. $\square$ Dairy (casein)- g. $\square$ Rotation diet $\begin{array}{ll}\text { free } & \text { h. } \square \text { No }\end{array}$
d. $\square$ Carbohydrate diet i. $\square$ Uncertain
e. $\square$ Candida diet

a. $\square \leq 30$ minutes

b. $\square 31-45$ minutes

c. $\square$ 46-60 minutes d. $\square$ 61-90 minutes

e. $\square>90$ minutes
Marked preference for specific food Frequency Mare b. $\square$ Rarely $(<10 \%)$ plate at ages 3 - 12 years? (please answer both Frequency and Duration headings)

c. $\square$ Sometimes $(10 \%-49 \%)$

d. $\square$ Often $(>50 \%)$ e. $\square$ Uncertain

\section{Frequency}

Insistence on eating with specific uten- a. $\square$ Never sils/dishes ats (please b. $\square$ Rarely $(<10 \%)$ sils/dishes at ages 3 - 12 years? (please headings) c. $\square$ Sometimes $(10 \%-49 \%)$

d. $\square$ Often $(>50 \%)$

e. $\square$ Uncertain
Duration

a. $\square$ Never

b. $\square<6$ months

c. $\square 6$ mo - 1 year

d. $\square>1$ year

e. $\square$ Uncertain

Duration

a. $\square$ Never

b. $\square<6$ months

c. $\square 6$ mo - 1 year

d. $\square>1$ year

e. $\square$ Uncertain

\section{Frequency}

a. $\square$ Never

b. $\square$ Rarely $(<10 \%)$

c. $\square$ Sometimes (10\%-49\%)

d. $\square$ Often $(>50 \%)$

e. $\square$ Uncertain

\section{Frequency}

a. $\square$ Never

b. $\square$ Rarely (<10\%)

c. $\square$ Sometimes (10\% - 49\%)

d. $\square$ Often (>50\%)

e. $\square$ Uncertain

\section{Frequency}

a. $\square$ Never

b. $\square$ Rarely $(<10 \%)$

c. $\square$ Sometimes (10 - 49\%)

d. $\square$ Often $(>50 \%)$

e. $\square$ Uncertain

\section{Frequency}

a. $\square$ Never

b. $\square$ Rarely $(<10 \%)$

c. $\square$ Sometimes (10\% - 49\%)

d. $\square$ Often $(>50 \%)$

e. $\square$ Uncertain
Fear of ingestion of new foods at ages b. $\square$ Rarely $(<10 \%)$

3 - 12 years? (please answer both c. $\square$ Sometimes

Frequency and Duration headings) $\quad(10 \%-49 \%)$

d. $\square$ Often $(>50 \%)$

e. $\square$ Uncertain

a. $\square$ Never

b. $\square<6$ months

c. $\square 6$ mo -1 year

d. $\square>1$ year

e. $\square$ Uncertain

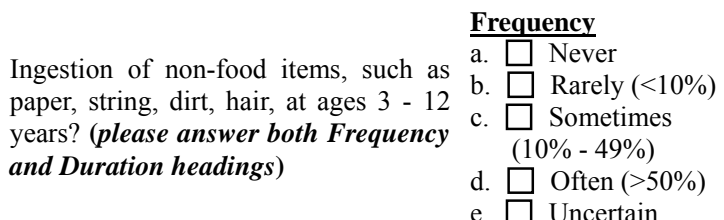

Duration

a. $\square$ Never

b. $\square<6$ months

c. $\square 6$ mo - 1 year

d. $\square>1$ year

e. $\square$ Uncertain

\section{Frequency}

a. $\square$ Never

b. $\square$ Rarely $(<10 \%)$

c. $\square$ Sometimes (10\% - 49\%)

d. $\square$ Often (>50\%)

e. $\square$ Uncertain

\section{Duration}

a. $\square$ Never

b. $\square<6$ months

c. $\square 6$ mo- 1 year

d. $\square>1$ year

e. $\square$ Uncertain

\section{Frequency}

Poor social mealtime behaviors (would a. $\square$ Never not sit with family, temper tantrum b. $\square$ Rarely $(<10 \%)$ during meal time, throwing food) at c. $\square$ Sometimes ages 3 - 12 years? (please answer both $(10 \%-49 \%)$

Frequency and Duration headings) d. $\square$ Often $(>50 \%)$

Duration

a. $\square$ Never

b. $\square<6$ months

c. $\square 6$ mo - 1 year

d. $\square>1$ year

e. $\square$ Uncertain
Frequency

a. $\square$ Never

b. $\square$ Rarely $(<10 \%)$

c. $\square$ Sometimes $(10 \%-49 \%)$

d. $\square$ Often $(>50 \%)$

e. $\square$ Uncertain

\section{Duration}

a. $\square$ Never

b. $\square<6$ months

c. $\square 6$ mo -1 year

d. $\square>1$ year

e. $\square$ Uncertain

e. $\square$ Uncertain

\section{Duration}

a. $\square$ Never

b. $\square<6$ months

c. $\square 6$ mo -1 year

d. $\square>1$ year

e. $\square$ Uncertain

\section{Duration \\ a. $\square$ Never \\ b. $\square<6$ months \\ c. $\square 6$ mo -1 year \\ d. $\square>1$ year \\ e. $\square$ Uncertain}

\section{Duration}

a. $\square$ Never

b. $\square<6$ months

c. $\square 6$ mo - 1 year

d. $\square>1$ year

e. $\square$ Uncertain 


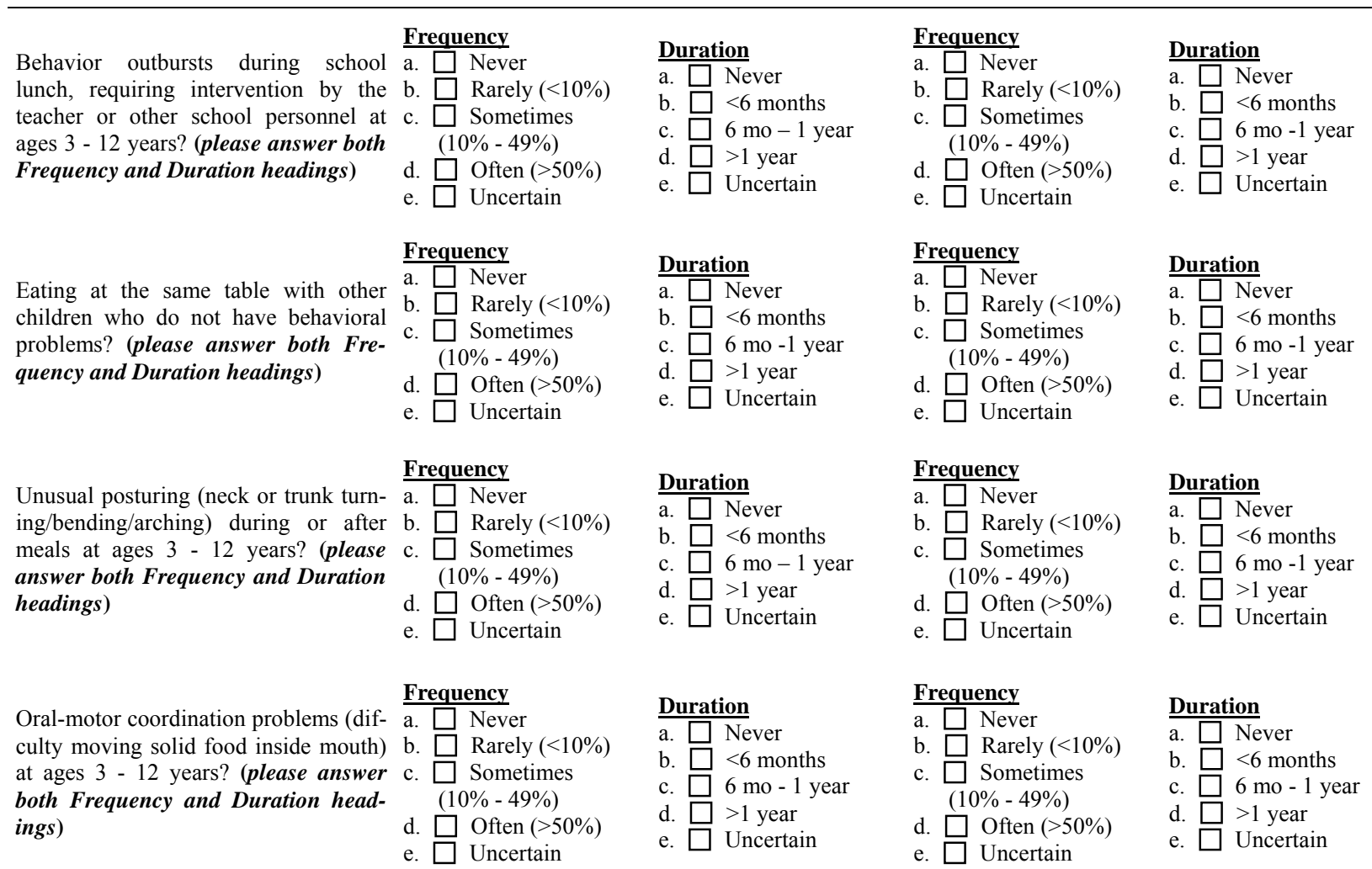

At what age did your child get toilet training for daytime bowel move- __ years $\square$ not yet toilet trained ments?

\begin{tabular}{|c|c|c|}
\hline \multirow{7}{*}{$\begin{array}{l}\text { Vomiting at ages } 3 \text { - } 12 \text { years? (please } \\
\text { answer both Frequency and Duration } \\
\text { headings) }\end{array}$} & Frequency & \\
\hline & Never & $\frac{\text { Duration }}{a+\text { Never }}$ \\
\hline & b. $\square$ Rarely $(<10 \%)$ & $\begin{array}{l}\text { Never } \\
\leq 6 \text { months }\end{array}$ \\
\hline & c. $\square$ Sometimes & $<6$ months \\
\hline & $(10 \%-49 \%)$ & $6 \mathrm{mo}-1 \mathrm{ye}$ \\
\hline & d. $\square$ Often $(>50 \%)$ & $>1$ year \\
\hline & e. $\square$ Uncertain & \\
\hline
\end{tabular}

Frequency

$\begin{array}{ll}\text { Diarrhea (more than } 3 \text { watery bowel } & \text { a. } \square \text { Never } \\ \text { movements per day) at ages } 3-12 & \text { b. } \square \text { Rarely }(<10 \%) \\ \text { years? (please answer both Frequency } & \text { c. } \square \text { Sometimes } \\ \begin{array}{ll}\text { and Duration headings) } & (10 \%-49 \%) \\ & \text { d. } \square \text { Often }(>50 \%) \\ & \text { e. } \square \text { Uncertain }\end{array}\end{array}$

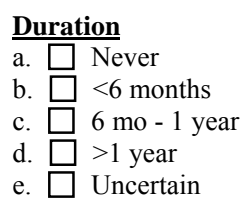

Frequency Constipation (more than 3 days be- a. $\square$ Never tween bowel movements) at ages 3 - b. $\square$ Rarely $(<10 \%)$ tween bowel movements) at ages 3 12 years? (please answer both

c. $\square$ Sometimes

$(10 \%-49 \%)$

d. $\square$ Often $(>50 \%)$

e. $\square$ Uncertain

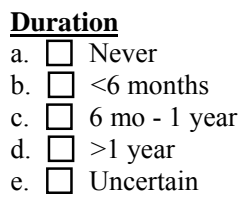

Frequency

a. $\square$ Never

Soiling in underpants or withholding b. $\square$ Rarely $(<10 \%)$ stool? (please answer both Frequency c. $\square$ Sometimes and Duration headings)

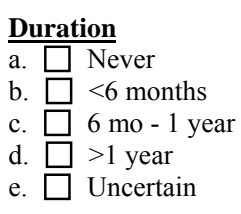

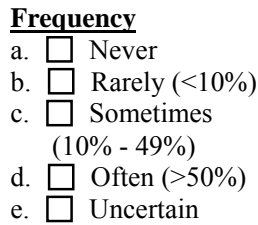

_ years $\square$ not yet toilet trained

$\begin{array}{ll}\text { Frequency } & \text { Duration } \\ \text { a. } \square \text { Never } & \text { a. } \square \text { Never } \\ \text { b. } \square \text { Rarely }(<10 \%) & \text { b. } \square<6 \text { months } \\ \text { c. } \square \text { Sometimes } & \text { c. } \square 6 \text { mo }-1 \text { year } \\ (10 \%-49 \%) & \text { d. } \square>1 \text { year } \\ \text { d. } \square \text { Often }(>50 \%) & \text { e. } \square \text { Uncertain } \\ \text { e. } \square \text { Uncertain } & \end{array}$

Frequency

a. $\square$ Never
b. $\square$ Rarely $(<10 \%)$
c. $\square$ Sometimes
d. $\square$ Often $(>50 \%)$
e. $\square$ Uncertain

Duration
a. $\square$ Never
b. $\square<6$ months
c. $\square 6$ mo - 1 year
d. $\square>1$ year
e. $\square$ Uncertain

Frequency

a. $\square$ Never
b. $\square$ Rarely $(<10 \%)$
c. $\square$ Sometimes
d. $\square$ Often $(>50 \%)$
e. $\square$ Uncertain

Duration

a. $\square$ Never

b. $\square<6$ months

c. $\square 6$ mo - 1 year

d. $\square>1$ year

e. $\square$ Uncertain 


\begin{tabular}{lll}
\hline & & a. $\square$ Yes \\
Inadequate/under weight or failure to $\square$ Yes & b. $\square$ No & b. $\square$ No \\
thrive at ages $3-12$ years? & c. $\square$ Uncertain & c. $\square$ Uncertain
\end{tabular}

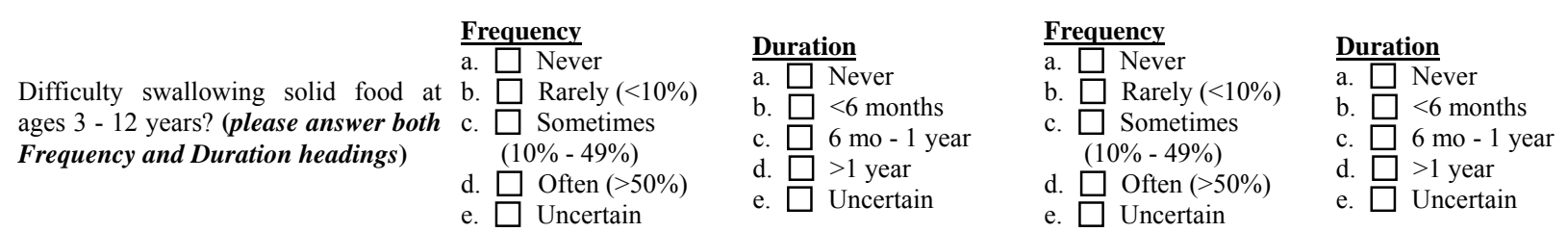

$\begin{array}{lll} & \begin{array}{l}\text { Frequency } \\ \text { Reflux / indigestion/ GERD/ esophagi- }\end{array} & \text { Duration } \\ \text { tis at ages 3-12 years? (please answer } & \text { b. } \square \text { Rarely }(<10 \%) & \text { a. } \square \text { Never } \\ \text { both Frequency and Duration head- } & \text { c. } \square \text { Sometimes } & \text { b. } \square<6 \text { months } \\ \text { ings) } & \text { d. } \square \text { Often }(>50 \%) & \text { c. } \square 6 \text { mo-1 year } \\ & \text { e. } \square \text { Uncertain } & \text { e. } \square \text { Uncertain }\end{array}$

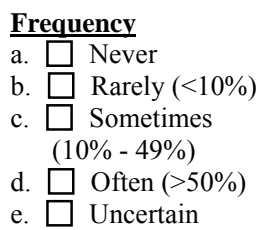

\section{Duration}

a. $\square$ Never

b. $\square<6$ months

c. $\square 6$ mo - 1 year

d. $\square>1$ year

e. $\square$ Uncertain
If you selected "b", "c", or "d" in the previous question, what tests did your a. $\square$ Barium swallow child have a test to confirm Reflux/ b. $\square \mathrm{pH}$ probe indigestion/GERD/ esophagitis at the c. $\square$ Endoscopy age of $3-12$ years? (please check all that apply)

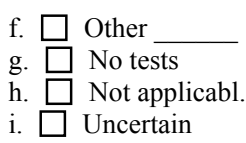

a. $\square$ Barium swallow

b. $\square \mathrm{pH}$ probe

c. $\square$ Endoscopy

d. $\square$ Biopsy

e. $\square$ Videofluoroscopy $\begin{array}{ll}\text { Food allergies at ages } 3-12 \text { years? } & \text { a. } \square \text { Milk } \\ \text { (please check all that apply) } & \text { c. } \square \text { Citrus } \\ & \text { d. } \square \text { Wheat }\end{array}$

Frequency

Abdominal pain requiring a doctor

visit at ages $3-12$ years? (please answer both Frequency and Duration headings)

a. $\square$ Never

b. $\square$ Rarely $(<10 \%)$

c. $\square$ Sometimes $(10 \%-49 \%)$

d. $\square$ Often $(>50 \%)$

e. $\square$ Uncertain

Celiac disease, proven by blood tests a. $\square$ Yes or by intestinal biopsy at ages $3-12$ b. $\square$ No years?

c. $\square$ Uncertain

Eosinophilic esophagitis proven by a. $\square$ Yes biopsy at ages $3-12$ years?

b. $\square$ No

c. $\square$ Uncertain

Diseases of small or large intestine at a. $\square$ Yes ages 3 - 12 years?

a. $\square$ Yes
b. $\square$ No
c. $\square$ Uncertain
a. $\square$ Zantac
b. $\square$ Pepcid
c. $\square$ Prevacid
d. $\square$ Prilosec

Medications for gastrointestinal probc. Prevacid

d. $\square$ Prilosec month at ages 3-12 years (check all e. $\square$ Flagyl that apply)

f. $\square$ Laxatives (e.g. Miralax, Milk of Magnesia, etc.)

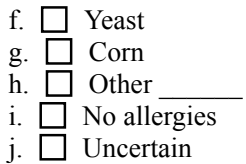
a. $\square$ Milk
b. $\square$ Eggs
c. $\square$ Citrus
d. $\square$ Whea

Duration
a. $\square$ Never
b. $\square<6$ months
c. $\square 6$ mo - 1 year
d. $\square>1$ year
e. $\square$ Uncertain

\section{Frequency}

a. $\square$ Never

b. $\square$ Rarely $(<10 \%)$

c. $\square$ Sometimes $(10 \%-49 \%)$

d. $\square$ Often $(>50 \%)$

e. $\square$ Uncertain

a. $\square$ Yes

b. $\square$ No

c. $\square$ Uncertain

a. $\square$ Yes

b. $\square$ No

c. $\square$ Uncertain

a. $\square$ Yes

b. $\square$ No

c. $\square$ Uncertain

a. $\square$ Zantac

b. $\square$ Pepcid

c. $\square$ Prevacid

d. $\square$ Prilosec

e. $\square$ Flagyl

f. $\square$ Laxatives (e.g. Miralax, Milk of Magnesia, etc.)

g. $\square$ Other

h. $\square$ Not applicable

a. $\square$ Gastroenterologist

b. $\square$ Dietician

c. $\square$ Nutritionist

d. $\square$ homeopathic practitioner

e. $\square$ integrative medicine specialist

f. $\square$ herbalist

g. $\square$ Other (please specify):
Duration

a. $\square$ Never

b. $\square<6$ months

c. $\square 6$ mo - 1 year

d. $\square>1$ year

e. $\square$ Uncertain
Who did your child see for his/her years? (check all that apply) c. $\square$ Nutritionist

d. $\square$ Homeopathic practitioner

f. $\square$ Herbalist

g. $\square$ Other (please specify): 
Is your child on Medicaid?

$\square$ yes $\square$ no

Estimate the total out-of-pocket (medical, drug, education, P.T., O.T., and speech therapy) expenditures in the year 20012 for your ASD child.

a. $\square$ Less than $\$ 1000$

b. $\square \$ 1000-\$ 5000$

c. $\square \$ 6000-\$ 10,000$

d. $\$ 11,000-\$ 25,000$

e. $\square>\$ 25,000$

a. $\square$ Less than $\$ 25,000$

b. $\square \$ 25,000-\$ 50,000$

What is your total household income?

c. $\square \$ 50,000$ - $\$ 75,000$

d. $\square>\$ 75,000$ yes $\square$ no

a. $\square$ Less than $\$ 1000$

b. $\$ 1000-\$ 5000$

c. $\square \$ 6000-\$ 10,000$

d. $\$ 11,000$ - $\$ 25,000$

e. $\square>\$ 25,000$

a. $\square$ Less than $\$ 25,000$

b. $\square \$ 25,000$ - $\$ 50,000$

c. $\square \$ 50,000$ - $\$ 75,000$

d. $\square>\$ 75,000$

THANK YOU VERY MUCH FOR YOUR TIME AND EFFORT. If you would like to receive a summary of these survey results, please write in your e-mail address 